\title{
Dimensional Changes in Co-Cr Alloys and Titanium Framework of Removable Partial Dentures Evaluation of the Dimensions of the Dental Clasps
}

\author{
SIMINA GAMAN 1 , CRISTINA MARIA BORTUN², MONICA SCRIECIU1, \\ VERONICA MERCUT ${ }^{1}$, ROXANA MARIA PASCU ${ }^{*}$, SANDA MIHAELA POPESCU ${ }^{1}$, \\ KAMEL EARAR ${ }^{3}$, RAMONA FEIER ${ }^{4 *}$, ANDREEA GABRIELA NICOLA ${ }^{1}$ \\ ${ }^{1}$ Craiova University of Medicine and Pharmacy, Dental Medicine Faculty, Department of Dental Prosthetics and Oral \\ Rehabilitation, 2 Petru Rares Str., 200349, Craiova, Romania \\ ${ }^{2}$ University of Medicine and Pharmacy "Victor Babes" Timisoara, Faculty of Dentistry, Dental Technology Specialization, \\ 9 Revolutiei Blvd., 300070, Timisoara, Romania \\ ${ }^{3}$ Dunarea de Jos University, Medicine \& Pharmacy Faculty, Dentistry Department, 47 Domneasca Str.,800008, Galati, \\ Romania \\ 4"Grigore T. Popa" University of Medicine and Pharmacy, Faculty of Dental Medicine, Department of Surgery, 16 \\ Universitatii Str.,700115, Iasi, Romania
}

\begin{abstract}
Removable partial denture are prosthetic solutions that replace missing teeth of partially edentulous patients, ensuring stomatognathic system functionality with affordable costs. The purpose of this study is to analyze the dimensional variations caused by the execution errors, which can lead to premature deterioration of the removable partial dentures and to conclude what sizes are deficient and can lead to the deterioration of the prosthetic part. The material involved in the present study was represented by the metal framework of 181 removable partial dentures. Of the total of 181 removable prosthetic parts, 88 were maxillary prostheses and 93 were mandibular prostheses. Measurements were made at the retentive arms, opposing arms, minor connectors, rests and junction areas between the body of the clasps and the active arms and studied compared to the edentulous classes. The results are focused on dimensional changes of both the retentive arms and the opposing arms of the clasps, which are roughly modeled in the first 3 edentulous classes, with a significant difference from those achieved in Kennedy's 4th class edentulous, where these segments of the clasps are much shorter. Regarding the size of the rests, although their thickness approximates the values indicated in the literature, they do not fit into the occlusal relief of the tooth. The length of the retentive arms varies according to the classes of edentulous, the clinical situation, but also the size and type of the tooth (premolars, molars) on which the clasp is applied. Regarding the opposing arm, the observed differences cannot be correlated with the objective criteria of their achievement because the attention is directed towards the realization of the retentive arm.
\end{abstract}

Keywords: Co-Cr alloys removable partial dentures, Ti removable partial dentures, retentive arm, opposing arm

\section{Introduction}

Removable partial denture are prosthetic restorations that replace missing teeth of partially edentulous patients, ensuring stomatognathic system functionality and having affordable costs [1]. These are made up of major connectors, minor connectors, direct retainer, indirect retainer, rests, stabilizing component and denture base [2-4]. The biocompatibility and mechanical properties of the cobalt / chromium alloys make them the current choice for the framework of the removable partial dentures [5].The retention force of the clasps depends on the modulus of elasticity of the metal from which they are made [6].Retention of the prosthesis is an essential condition in terms of the comfort of the patient with the prosthesis, because its vertical displacements can cause pain, tissue trauma and discomfort [7]. The arms of the clasps have an important role in anchoring the removable partial 
dentures at the level of the teeth, having to deform both at the insertion and at its removal [8]. There is an interrelation between the dimensions, strength and casting technology of the metallic alloy from which the prosthetic restoration is made. The resistance of the framework can be maintained only if its component elements are made to the appropriate dimensions, while also respecting the casting and processing stages of the metallic alloy. In addition, internal structural defects can also overlap, which shows that the thick castings hide defects, which can, over time, get on surface, becoming visible. For the success of the technical realization of a prosthesis, it is necessary to use models with a series of calibrated waxes, to make solid joints between the components of the model and to respect the indications of the companies producing dental materials. Reduce of some areas can be followed by deformations or fractures, with repercussions on the maintenance, support and stability of the metallic framework. The oversized dimensions appear when technology projects a more solid structure and penetrates into the details of the pattern [2-4]. The oversized dimensions must be corrected in the dental office or laboratory, by grinding and then by polishing [9]. Up to $75 \%$ of the removable partial dentures have a poor adaptation at the time of insertion. This can contribute to the mobilization of the teeth and the discomfort of the patient [10]. RPD design and the condition of abutment teeth can significantly influence the health of the remaining teeth [11]. Although traditional removable partial dentures also offer an accessible treatment alternative for partial edentulous cases, they may represent a risk to the remaining teeth, predisposing to bacterial plaque formation, dental tartar as well as biomechanical overload [12]. However, the attempt to replace the metallic framework with thermoplastic resins did not give very good results, and more clinical and theoretical studies are needed in the future [13]. In the study, measurements were made of the clasps arms to detect any defects. These defects detected at the level of the framework can result during the preparation in the stages of waxing, casting, finishing and polishing.

The purpose of this study is to analyze the dimensional variations caused by the execution errors, which can lead to premature deterioration of the removable partial dentures and to conclude what sizes are deficient and can lead to the deterioration of the prosthetic part.

\section{Experimental part}

The material involved in the present study was represented by the metallic framework of 181 removable partial dentures, made by the students from the Dental Technical Specialization, the Discipline Technology of the Dental Prosthesis from UMF "V.B." Timişoara. Out of the total of 181 removable partial dentures, 88 were maxillary prostheses and 93 were mandibular prostheses (Figure 1 $a, b)$.

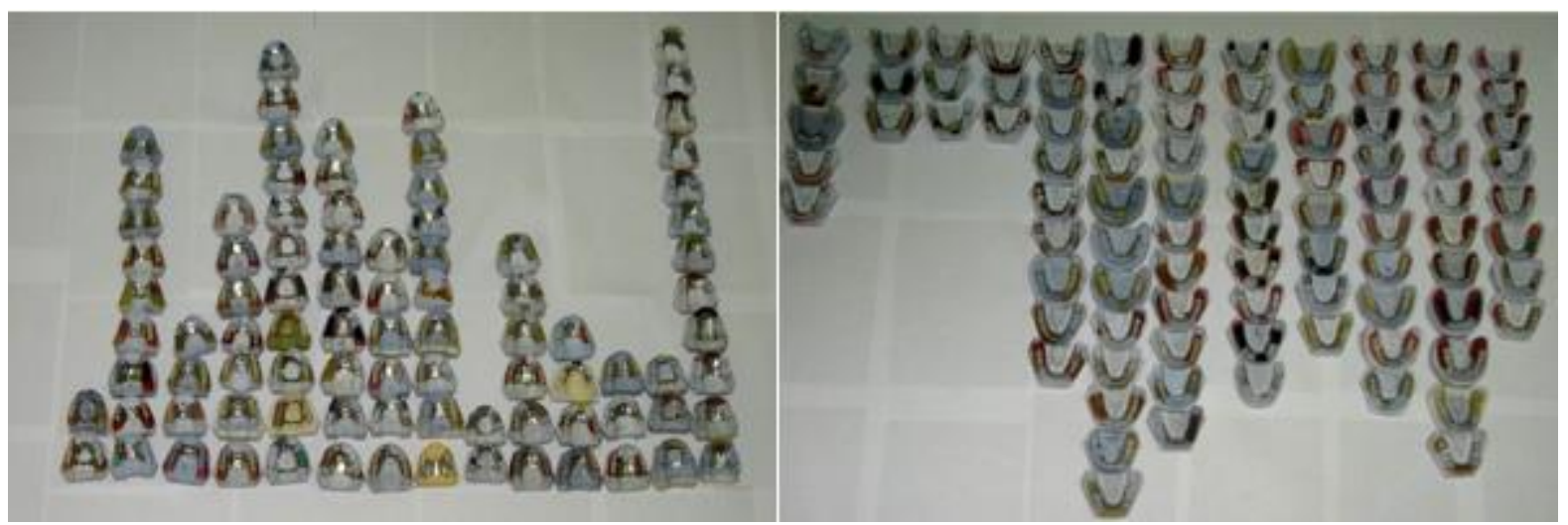

Figure 1. a. maxillary and b. mandibular removable prostheses

The metal framework of the prostheses was made on the classic Kennedy edentulous classes. Their design varied because it included both Kennedy's pure edentulous classes as well as classes with a series 
of changes. Basically, each metal framework was made on a different type of edentulous, which made the evaluation to include a wide variety of clinical situations. Measurements were made at the retentive arms, opposing arms, minor connectors, rests and junction areas between the body of the clasps and the active arms and compared with the edentulous classes. The measurement of the components of the clasps was performed with a digital measuring MT Digitale Schiebelehre 3406 (CEGermania, 2007) and with the thickness gauge (Figures 2, 3).

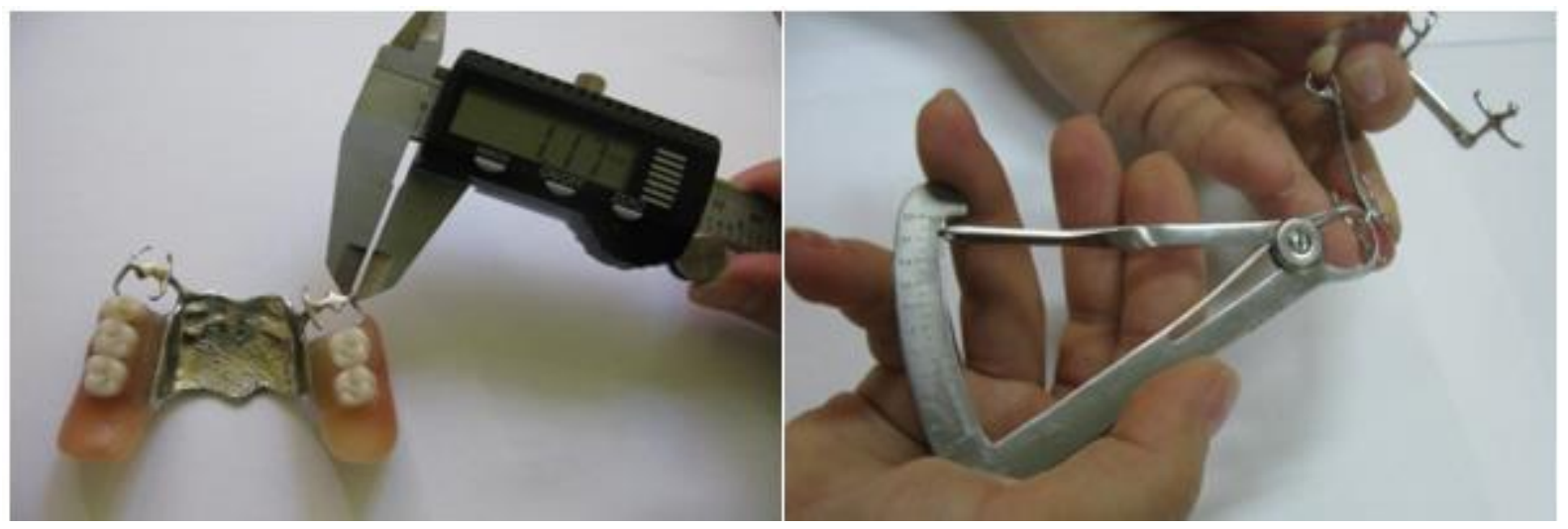

Figure 2,3. Measurement with the digital probe and thickness gauge

The "read" parameters were: length, width at the base (near the body of the clasps), at the top, thickness or height at the base and at the free end of the clasps.

The measurement (dimensions) of the component elements of the framework prostheses was the method of study of our research.

The statistical evaluations of the measurements were made with the program SPSS Statistics 17.0. Comparisons between classes were made with the ANOVA OneWay. In order to determine which of the classes differ significantly (Graph1), the comparisons between classes were refined, with the Scheffe post hoc test. The variables studied being numerical were calculated: the average, the standard deviation, the standard error of the average, the interval limits of the $95 \%$ confidence for the average value and the minimum and maximum values, values foreseen in all our studies. We systematized the data by comparing the quality of Bonwill and Ackers circular cast clasps on Kennedy edentulous classes.

\section{Results and discussions}

Statistical data on the size of the retentive arms of the different clasps currently used in the technology of the removable partial dentures are presented in the following tables and graphs.

The values of the measurements for the Bonwill clasps - the active arm (Table 1) were initially reproduced because they had obvious dimensional changes, but also frequent deterioration.

Table 1. Statistical data on the size of the retentive arm of the bonwill clasp

\begin{tabular}{|c|c|c|c|c|c|c|c|c|c|}
\hline \multirow{2}{*}{$\begin{array}{c}\text { Bonwill } \\
\text { clasp } \\
\text { Retentive } \\
\text { arm }\end{array}$} & \multirow[b]{2}{*}{ Class } & \multirow[b]{2}{*}{ No. } & \multirow[b]{2}{*}{ Average } & \multirow{2}{*}{$\begin{array}{r}\text { Standard } \\
\text { deviation }\end{array}$} & \multirow{2}{*}{$\begin{array}{l}\text { Standard } \\
\text { error of } \\
\text { the } \\
\text { average }\end{array}$} & \multicolumn{2}{|c|}{$\begin{array}{l}95 \% \text { confidence interval for } \\
\text { the average }\end{array}$} & \multirow[b]{2}{*}{ Min. } & \multirow[b]{2}{*}{ Max. } \\
\hline & & & & & & $\begin{array}{l}\text { Inferior } \\
\text { limit }\end{array}$ & $\begin{array}{l}\text { Upper } \\
\text { limit }\end{array}$ & & \\
\hline \multirow{5}{*}{ Length } & I & 14 & 9.24 & 1.419 & 0.379 & 8.416 & 10.055 & 7.9 & 12.1 \\
\hline & II & 34 & 8.28 & 1.071 & 0.184 & 7.909 & 8.656 & 5.9 & 11.0 \\
\hline & III & 13 & 9.22 & 1.700 & 0.472 & 8.188 & 10.243 & 6.9 & 12.5 \\
\hline & IV & 19 & 9.36 & 1.535 & 0.352 & 8.623 & 10.103 & 6.5 & 12.2 \\
\hline & Total & 80 & 8.86 & 1.427 & 0.160 & 8.540 & 9.175 & 5.9 & 12.5 \\
\hline Width at & I & 14 & 1.68 & 0.304 & 0.081 & 1.503 & 1.854 & 1.0 & 2.1 \\
\hline
\end{tabular}




\begin{tabular}{|c|c|c|c|c|c|c|c|c|c|}
\hline \multirow[t]{4}{*}{ the base } & II & 34 & 1.92 & 0.341 & 0.058 & 1.802 & 2.040 & 1.2 & 2.7 \\
\hline & III & 13 & 1.94 & 0.290 & 0.080 & 1.763 & 2.114 & 1.5 & 2.5 \\
\hline & IV & 19 & 2.03 & 0.166 & 0.038 & 1.946 & 2.106 & 1.7 & 2.4 \\
\hline & Total & 80 & 1.91 & 0.309 & 0.035 & 1.837 & 1.975 & 1.0 & 2.7 \\
\hline \multirow{5}{*}{$\begin{array}{l}\text { Width at } \\
\text { the top }\end{array}$} & I & 14 & 1.29 & 0.268 & 0.072 & 1.131 & 1.441 & 0.8 & 1.7 \\
\hline & II & 34 & 1.28 & 0.305 & 0.052 & 1.170 & 1.383 & 0.8 & 1.9 \\
\hline & III & 13 & 1.67 & 0.290 & 0.080 & 1.494 & 1.844 & 1.1 & 2.1 \\
\hline & IV & 19 & 1.17 & 0.264 & 0.061 & 1.046 & 1.301 & 0.7 & 1.7 \\
\hline & Total & 80 & 1.32 & 0.325 & 0.036 & 1.245 & 1.390 & 0.7 & 2.1 \\
\hline \multirow{5}{*}{$\begin{array}{l}\text { Height at } \\
\text { the base }\end{array}$} & I & 14 & 1.30 & 0.239 & 0.064 & 1.162 & 1.438 & 0.8 & 1.7 \\
\hline & II & 34 & 1.35 & 0.245 & 0.042 & 1.264 & 1.436 & 1.0 & 1.9 \\
\hline & III & 13 & 1.48 & 0.423 & 0.117 & 1.222 & 1.732 & 0.7 & 2.1 \\
\hline & IV & 19 & 1.34 & 0.263 & 0.060 & 1.215 & 1.469 & 0.9 & 1.8 \\
\hline & Total & 80 & 1.36 & 0.284 & 0.032 & 1.297 & 1.423 & 0.7 & 2.1 \\
\hline \multirow{5}{*}{$\begin{array}{l}\text { Height at } \\
\text { the top }\end{array}$} & I & 14 & 0.84 & 0.160 & 0.043 & 0.750 & 0.935 & 0.6 & 1.1 \\
\hline & II & 34 & 0.92 & 0.239 & 0.041 & 0.840 & 1.007 & 0.4 & 1.3 \\
\hline & III & 13 & 0.95 & 0.293 & 0.081 & 0.777 & 1.131 & 0.5 & 1.5 \\
\hline & IV & 19 & 0.84 & 0.195 & 0.045 & 0.748 & 0.936 & 0.5 & 1.1 \\
\hline & Total & 80 & 0.90 & 0.228 & 0.025 & 0.844 & 0.946 & 0.4 & 1.5 \\
\hline
\end{tabular}

Anova test results showed significant differences in length $(\mathrm{p}=0.018, \alpha=0.05)$, width at base $(\mathrm{p}=$ $0.011, \alpha=0.01)$ and width at the top $(\mathrm{p}<0.001, \alpha=0.001)$. The data were also grouped according to Kennedy edentation classes, as shown in graph 1.

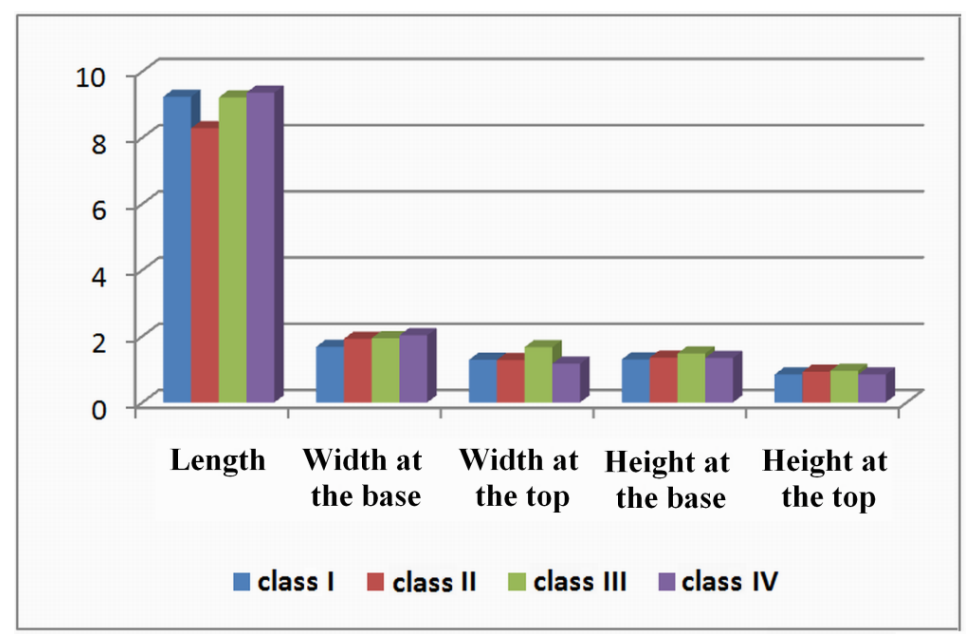

Graph 1. Evaluation of the Bonwill clasp - Retentive arm

Scheffe post hoc test results showed significant differences in cases:

- The length of the arms from class II is significantly lower than the length of the IV class ( $\mathrm{p}=$ $0.041, \alpha=0.05)$ - an unexplained fact when comparing claps with the same position on the arch

- The width at the base for class I is significantly smaller than that of the class IV ( $p=0.014, \alpha=$ 0.05), which often causes the clasp fracture.

- The width at the top of the arms in class I is significantly smaller than the width of the III class $(\mathrm{p}=0.01, \alpha=0.05)$

- The width at the top of the arms in class II is smaller than that of the III class ( $p=0.001, \alpha=$ $0.01)$ 
- The width at the top of the arms in class III is significantly greater than that of the II class (p $<0.001, \alpha=0.001)$

The statistical data obtained after measuring the aforementioned landmarks of the active arm of the Ackers clasp are shown in Table 2.

Table 2. Statistical data on the size of the retentive arm of the ackers clasp

\begin{tabular}{|c|c|c|c|c|c|c|c|c|c|}
\hline \multirow{2}{*}{$\begin{array}{c}\text { Ackers } \\
\text { clasp - } \\
\text { Retentive } \\
\text { arm }\end{array}$} & \multirow[b]{2}{*}{ Class } & \multirow{2}{*}{ No. } & \multirow{2}{*}{ Average } & \multirow{2}{*}{$\begin{array}{l}\text { Standard } \\
\text { deviation }\end{array}$} & \multirow{2}{*}{$\begin{array}{l}\text { Standard } \\
\text { error of } \\
\text { the } \\
\text { average }\end{array}$} & \multicolumn{2}{|c|}{$\begin{array}{l}95 \% \text { confidence interval for } \\
\text { the average }\end{array}$} & \multirow{2}{*}{ Min. } & \multirow{2}{*}{ Max. } \\
\hline & & & & & & $\begin{array}{l}\text { Inferior } \\
\text { limit }\end{array}$ & $\begin{array}{l}\text { Upper } \\
\text { limit }\end{array}$ & & \\
\hline \multirow{5}{*}{ Length } & I & 42 & 7.44 & 1.234 & 0.190 & 7.051 & 7.820 & 5.5 & 10.0 \\
\hline & II & 64 & 7.43 & 1.649 & 0.206 & 7.019 & 7.843 & 4.5 & 12.0 \\
\hline & III & 37 & 8.35 & 1.704 & 0.280 & 7.783 & 8.919 & 5.0 & 13.0 \\
\hline & IV & 15 & 7.67 & 1.858 & 0.480 & 6.637 & 8.696 & 3.0 & 10.0 \\
\hline & Total & 158 & 7.67 & 1.615 & 0.129 & 7.416 & 7.924 & 3.0 & 13.0 \\
\hline \multirow{5}{*}{$\begin{array}{l}\text { Width at } \\
\text { the base }\end{array}$} & I & 42 & 1.76 & 0.281 & 0.043 & 1.674 & 1.849 & 1.1 & 2.2 \\
\hline & II & 64 & 1.73 & 0.347 & 0.043 & 1.646 & 1.819 & 1.0 & 2.3 \\
\hline & III & 37 & 1.78 & 0.227 & 0.037 & 1.708 & 1.859 & 1.5 & 2.1 \\
\hline & IV & 15 & 1.69 & 0.358 & 0.093 & 1.488 & 1.885 & 1.0 & 2.0 \\
\hline & Total & 158 & 1.75 & 0.305 & 0.024 & 1.700 & 1.796 & 1.0 & 2.3 \\
\hline \multirow{5}{*}{$\begin{array}{l}\text { Width at } \\
\text { the top }\end{array}$} & I & 42 & 1.26 & 0.294 & 0.045 & 1.173 & 1.356 & 0.8 & 1.9 \\
\hline & II & 64 & 1.30 & 0.293 & 0.037 & 1.228 & 1.375 & 0.8 & 1.9 \\
\hline & III & 37 & 1.35 & 0.352 & 0.058 & 1.234 & 1.469 & 0.7 & 2.0 \\
\hline & IV & 15 & 1.36 & 0.352 & 0.091 & 1.165 & 1.555 & 0.9 & 2.1 \\
\hline & Total & 158 & 1.31 & 0.313 & 0.025 & 1.260 & 1.358 & 0.7 & 2.1 \\
\hline \multirow{5}{*}{$\begin{array}{l}\text { Height at } \\
\text { the base }\end{array}$} & I & 42 & 1.33 & 0.271 & 0.042 & 1.244 & 1.413 & 0.9 & 1.9 \\
\hline & II & 64 & 1.24 & 0.357 & 0.045 & 1.148 & 1.327 & 0.5 & 1.9 \\
\hline & III & 37 & 1.41 & 0.374 & 0.062 & 1.281 & 1.530 & 0.7 & 2.1 \\
\hline & IV & 15 & 1.09 & 0.420 & 0.108 & 0.861 & 1.326 & 0.5 & 2.0 \\
\hline & Total & 158 & 1.29 & 0.356 & 0.028 & 1.231 & 1.343 & 0.5 & 2.1 \\
\hline \multirow{5}{*}{$\begin{array}{l}\text { Height at } \\
\text { the top }\end{array}$} & I & 42 & 0.79 & 0.222 & 0.034 & 0.724 & 0.862 & 0.4 & 1.3 \\
\hline & II & 64 & 1.00 & 0.316 & 0.040 & 0.921 & 1.079 & 0.4 & 1.8 \\
\hline & III & 37 & 0.93 & 0.392 & 0.064 & 0.796 & 1.058 & 0.4 & 1.8 \\
\hline & IV & 15 & 1.09 & 0.363 & 0.094 & 0.892 & 1.295 & 0.5 & 1.8 \\
\hline & Total & 158 & 0.94 & 0.331 & 0.026 & 0.885 & 0.989 & 0.4 & 1.8 \\
\hline
\end{tabular}

Significant differences were obtained for length $(p=0.03, \alpha=0.05)$, height at the base $(p=0.014$, $\alpha=0.05)$, and height at the top $(\mathrm{p}=0.003, \alpha=0.01)$ - with the OneWay ANOVA test.

With the Scheffe post hoc test, the following differences were obtained for Kennedy edentation classes: $0.05)$

- The length of the arms in class I is reduced compared to the length of class III ( $p=0.046, \alpha=$

- The length of the arms class II is reduced compared to the length of class III ( $p=0.042, \alpha=$ $0.05)$

- The height at the base of the clasp is higher for the III class than for the IV class $(p=0.038, \alpha=$ $0.05)$

- The height at the top of the clasp is significantly reduced in class I than in class II ( $\mathrm{p}=0.016, \alpha=$ $0.05)$ 
- Height is significantly reduced in Kennedy's 1 st class than Kennedy's 4th class $(p=0.023, \alpha=$ $0.05)$

The dimensional evaluation of the Akers clasps active arm is shown in Graph 2.

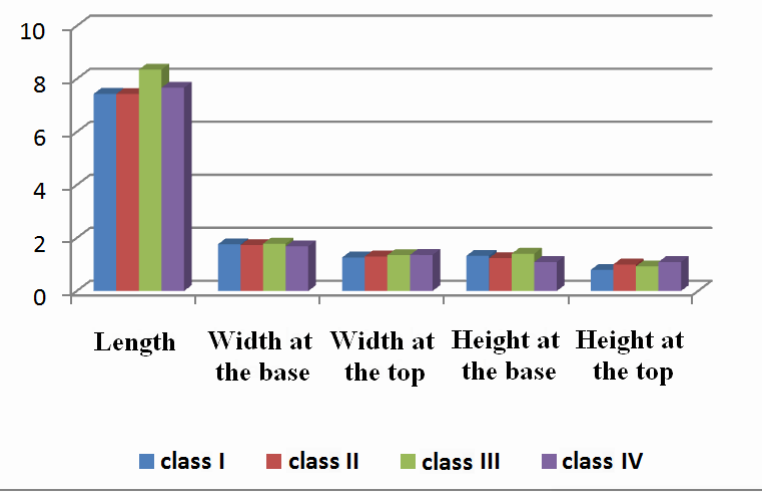

Graph 2. Evaluation of Akers clasp - Retentive arm

The data obtained by measuring the opposite arms were analyzed according to the same method. The first evaluated clasps are the Bonwill clasp, the measured data being presented in table 3 .

Table 3. Evaluation of the profile of the bonwill clasp opposing arm

\begin{tabular}{|c|c|c|c|c|c|c|c|c|c|}
\hline \multirow{2}{*}{$\begin{array}{l}\text { Bonwill } \\
\text { Clasp }\end{array}$} & \multirow{2}{*}{ Class } & \multirow{2}{*}{ No. } & \multirow{2}{*}{ Average } & \multirow{2}{*}{$\begin{array}{l}\text { Standard } \\
\text { deviation }\end{array}$} & \multirow{2}{*}{$\begin{array}{c}\text { Standard error } \\
\text { of the average } \\
95 \%\end{array}$} & \multicolumn{2}{|c|}{$\begin{array}{l}95 \% \text { confidence interval for the } \\
\text { average }\end{array}$} & \multirow{2}{*}{ Min. } & \multirow{2}{*}{ Max. } \\
\hline & & & & & & $\begin{array}{l}\text { Inferior } \\
\text { limit }\end{array}$ & $\begin{array}{l}\text { Upper } \\
\text { limit }\end{array}$ & & \\
\hline \multirow{5}{*}{ Length } & I & 14 & 6.94 & 1.985 & 0.531 & 5.797 & 8.089 & 4.3 & 12.0 \\
\hline & II & 34 & 7.63 & 1.132 & 0.194 & 7.232 & 8.021 & 5.0 & 10.2 \\
\hline & III & 13 & 6.72 & 1.559 & 0.432 & 5.781 & 7.665 & 4.1 & 9.0 \\
\hline & IV & 19 & 6.45 & 1.370 & 0.314 & 5.792 & 7.113 & 4.0 & 9.0 \\
\hline & Total & 80 & 7.08 & 1.493 & 0.167 & 6.749 & 7.413 & 4.0 & 12.0 \\
\hline \multirow{5}{*}{$\begin{array}{l}\text { Width at } \\
\text { the base }\end{array}$} & I & 14 & 1.65 & 0.447 & 0.119 & 1.392 & 1.908 & 0.9 & 2.4 \\
\hline & II & 34 & 1.82 & 0.236 & 0.041 & 1.741 & 1.906 & 1.2 & 2.4 \\
\hline & III & 13 & 2.00 & 0.394 & 0.109 & 1.762 & 2.238 & 1.3 & 2.6 \\
\hline & IV & 19 & 1.85 & 0.385 & 0.088 & 1.667 & 2.038 & 1.3 & 2.8 \\
\hline & Total & 80 & 1.83 & 0.352 & 0.039 & 1.750 & 1.907 & 0.9 & 2.8 \\
\hline \multirow{5}{*}{$\begin{array}{l}\text { Width at } \\
\text { the top }\end{array}$} & I & 14 & 1.31 & 0.291 & 0.078 & 1.147 & 1.482 & 0.6 & 1.8 \\
\hline & II & 34 & 1.46 & 0.241 & 0.041 & 1.372 & 1.540 & 1.0 & 1.8 \\
\hline & III & 13 & 1.58 & 0.460 & 0.128 & 1.307 & 1.862 & 0.9 & 2.2 \\
\hline & IV & 19 & 1.54 & 0.490 & 0.112 & 1.306 & 1.778 & 0.9 & 2.4 \\
\hline & Total & 80 & 1.47 & 0.365 & 0.041 & 1.391 & 1.554 & 0.6 & 2.4 \\
\hline \multirow{5}{*}{$\begin{array}{l}\text { Height at } \\
\text { the base }\end{array}$} & I & 14 & 1.36 & 0.350 & 0.094 & 1.162 & 1.566 & 0.4 & 1.9 \\
\hline & II & 34 & 1.39 & 0.238 & 0.041 & 1.305 & 1.471 & 0.9 & 1.9 \\
\hline & III & 13 & 1.07 & 0.202 & 0.056 & 0.947 & 1.191 & 0.9 & 1.5 \\
\hline & IV & 19 & 1.14 & 0.239 & 0.055 & 1.022 & 1.252 & 0.7 & 1.6 \\
\hline & Total & 80 & 1.27 & 0.286 & 0.032 & 1.209 & 1.336 & 0.4 & 1.9 \\
\hline \multirow{5}{*}{$\begin{array}{l}\text { Height at } \\
\text { the top }\end{array}$} & I & 14 & 0.98 & 0.294 & 0.079 & 0.809 & 1.148 & 0.5 & 1.5 \\
\hline & II & 34 & 0.87 & 0.264 & 0.045 & 0.781 & 0.966 & 0.4 & 1.4 \\
\hline & III & 13 & 0.85 & 0.288 & 0.080 & 0.680 & 1.028 & 0.4 & 1.4 \\
\hline & IV & 19 & 0.80 & 0.211 & 0.048 & 0.698 & 0.902 & 0.5 & 1.2 \\
\hline & Total & 80 & 0.87 & 0.264 & 0.030 & 0.813 & 0.930 & 0.4 & 1.5 \\
\hline
\end{tabular}


Comparisons between classes showed significant differences in length $(p=0.029, \alpha=0.05)$ and height at baseline $(\mathrm{p}<0.001, \alpha=0.001)$.

The comparisons between 2 classes were refined, the significant differences were obtained in the cases (graph 3):

- The length of thearms in class II is significantly increased compared to the length of the fourth class $(\mathrm{p}=0.04, \alpha=0.05)$

- The height at the base for the 1 st class is significantly higher than the one for the 3 rd class $(\mathrm{p}=$ $0.036, \alpha=0.05)$

- The height at the base for the second class is significantly higher than that of the third class ( $\mathrm{p}$ $=0.004, \alpha=0.01$ )

- The height at the base for the second class is significantly higher than that of the fourth class (p $=0.012, \alpha=0.05)$

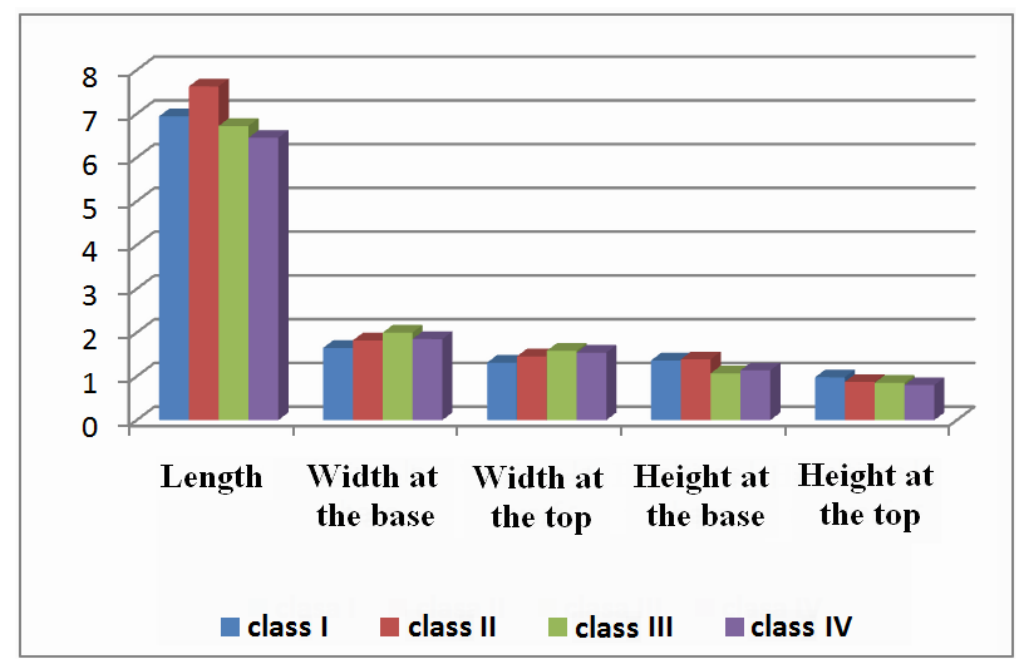

Graph 3. Evaluation of the opposing arm. Bonwill clasp

The evaluation of the opposing arm made at the Ackers clasp, the prototype of the circular clasp, was made based on the data presented in table 4, and the comparative aspects by edentation classes in graph 4.

Table 4. Evaluation of the profile of the ackers clasp opposing arm.

\begin{tabular}{|c|c|c|c|c|c|c|c|c|c|}
\hline \multirow{2}{*}{$\begin{array}{l}\text { Ackers } \\
\text { claps }\end{array}$} & \multirow{2}{*}{ Class } & \multirow{2}{*}{ No. } & \multirow{2}{*}{ Average } & \multirow{2}{*}{$\begin{array}{l}\text { Standard } \\
\text { deviation }\end{array}$} & \multirow{2}{*}{$\begin{array}{l}\text { Standard error } \\
\text { of the average }\end{array}$} & \multicolumn{2}{|c|}{$\begin{array}{l}95 \% \text { confidence interval for the } \\
\text { average }\end{array}$} & \multirow{2}{*}{ Min. } & \multirow{2}{*}{ Max. } \\
\hline & & & & & & $\begin{array}{l}\text { Inferior } \\
\text { limit }\end{array}$ & $\begin{array}{l}\text { Upper } \\
\text { limit }\end{array}$ & & \\
\hline \multirow{5}{*}{ Length } & I & 42 & 7.87 & 1.342 & 0.207 & 7.448 & 8.285 & 4.0 & 10.0 \\
\hline & II & 64 & 7.78 & 1.837 & 0.230 & 7.324 & 8.242 & 2.4 & 11.0 \\
\hline & III & 37 & 7.76 & 1.934 & 0.318 & 7.115 & 8.404 & 2.5 & 10.0 \\
\hline & IV & 15 & 6.30 & 1.824 & 0.471 & 5.290 & 7.310 & 3.0 & 10.0 \\
\hline & Total & 158 & 7.66 & 1.782 & 0.142 & 7.379 & 7.939 & 2.4 & 11.0 \\
\hline \multirow{5}{*}{$\begin{array}{l}\text { Width at } \\
\text { the base }\end{array}$} & I & 42 & 1.76 & 0.333 & 0.051 & 1.661 & 1.868 & 1.0 & 2.3 \\
\hline & II & 64 & 1.84 & 0.327 & 0.041 & 1.754 & 1.918 & 1.1 & 2.5 \\
\hline & III & 37 & 1.86 & 0.305 & 0.050 & 1.758 & 1.961 & 1.2 & 2.6 \\
\hline & IV & 15 & 1.78 & 0.369 & 0.095 & 1.576 & 1.984 & 1.4 & 2.6 \\
\hline & Total & 158 & 1.82 & 0.327 & 0.026 & 1.766 & 1.868 & 1.0 & 2.6 \\
\hline \multirow{2}{*}{$\begin{array}{l}\text { Width at } \\
\text { the top }\end{array}$} & I & 42 & 1.44 & 0.334 & 0.051 & 1.339 & 1.547 & 0.9 & 2.0 \\
\hline & II & 64 & 1.43 & 0.378 & 0.047 & 1.340 & 1.529 & 0.8 & 2.2 \\
\hline
\end{tabular}




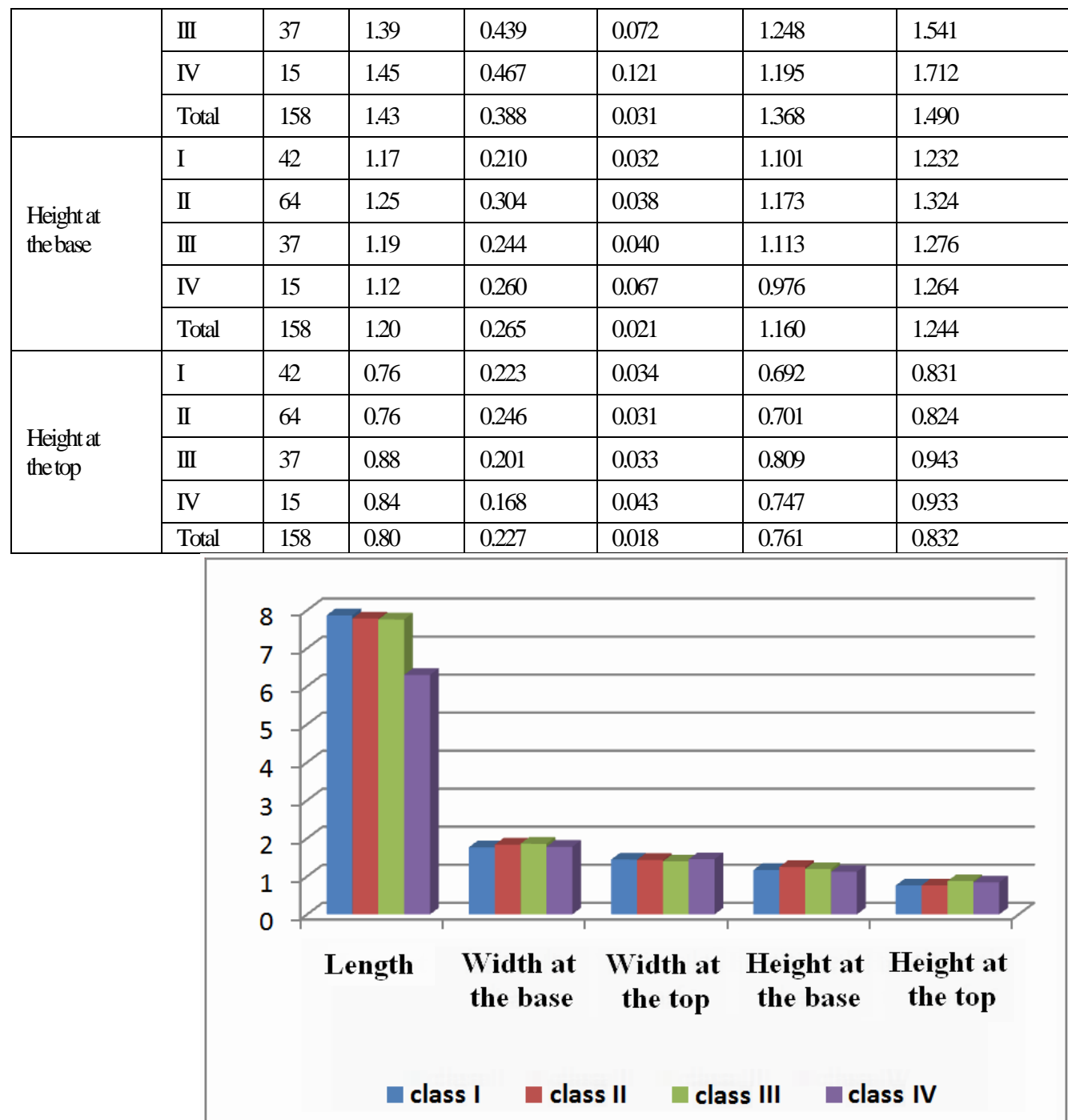

Graph 4. Evaluation of the opposing arm of the Ackers clasp

After class comparisons, in this case, significant differences were obtained for length only $(\mathrm{p}=$ $0.02, \alpha=0.05)$.

The classes that differ significantly, the comparisons between classes were refined and significant differences were obtained in the cases:

- The length of the arms in class I is significantly increased compared to the length of class IV ( $p=$ $0.033, \alpha=0.05$ )

- The length of the arms in class II is significantly increased compared to the length of the fourth class $(\mathrm{p}=0.035, \alpha=0.05)$

- The length of the arms in class III is significantly increased compared to the length of class IV ( $p$ $=0.042, \alpha=0.05$ ).

The evaluation of the size of the occlusal rests from different clasps, as component elements of theremovable partial dentures was done on edentation classes and are presented on the same types of clasps presented above (Table 5, Graph 5). 
Table 5. Evaluation of the rests of bonwill clasps

\begin{tabular}{|c|c|c|c|c|c|c|c|c|c|}
\hline \multirow{2}{*}{$\begin{array}{c}\text { Bonwill } \\
\text { clasp } \\
\text { rests }\end{array}$} & \multirow{2}{*}{ Class } & \multirow{2}{*}{ No. } & \multirow{2}{*}{ Average } & \multirow{2}{*}{$\begin{array}{l}\text { Standard } \\
\text { deviation }\end{array}$} & \multirow{2}{*}{$\begin{array}{c}\text { Standard } \\
\text { error at } \\
\text { the } \\
\text { average }\end{array}$} & \multicolumn{2}{|c|}{$\begin{array}{l}95 \% \text { confidence interval } \\
\text { for the average }\end{array}$} & \multirow{2}{*}{ Min. } & \multirow{2}{*}{ Max } \\
\hline & & & & & & $\begin{array}{l}\text { Inferior } \\
\text { limit }\end{array}$ & $\begin{array}{l}\text { Upper } \\
\text { limit }\end{array}$ & & \\
\hline \multirow{5}{*}{ Length } & I & 13 & 2.28 & 0.402 & 0.111 & 2.042 & 2.527 & 1.8 & 2.9 \\
\hline & II & 32 & 2.17 & 0.362 & 0.064 & 2.041 & 2.302 & 1.7 & 3.0 \\
\hline & III & 13 & 2.35 & 0.475 & 0.132 & 2.067 & 2.641 & 1.8 & 3.1 \\
\hline & IV & 18 & 2.45 & 0.451 & 0.106 & 2.225 & 2.675 & 1.5 & 3.2 \\
\hline & Total & 76 & 2.29 & 0.419 & 0.048 & 2.193 & 2.384 & 1.5 & 3.2 \\
\hline \multirow{5}{*}{ Width } & I & 13 & 2.19 & 0.435 & 0.121 & 1.930 & 2.455 & 1.6 & 3.0 \\
\hline & II & 32 & 2.02 & 0.352 & 0.062 & 1.895 & 2.149 & 1.5 & 2.7 \\
\hline & III & 13 & 2.24 & 0.427 & 0.119 & 1.980 & 2.497 & 1.5 & 2.9 \\
\hline & IV & 18 & 2.34 & 0.448 & 0.105 & 2.122 & 2.567 & 1.6 & 3.1 \\
\hline & Total & 76 & 2.16 & 0.417 & 0.048 & 2.069 & 2.260 & 1.5 & 3.1 \\
\hline \multirow{5}{*}{ Thickness } & I & 13 & 1.45 & 0.341 & 0.094 & 1.248 & 1.660 & 1.0 & 2.0 \\
\hline & II & 32 & 1.54 & 0.404 & 0.071 & 1.398 & 1.689 & 0.8 & 2.0 \\
\hline & III & 13 & 1.66 & 0.496 & 0.138 & 1.362 & 1.961 & 0.9 & 2.5 \\
\hline & IV & 17 & 1.43 & 0.488 & 0.118 & 1.178 & 1.680 & 0.5 & 2.1 \\
\hline & Total & 75 & 1.52 & 0.430 & 0.050 & 1.424 & 1.622 & 0.5 & 2.5 \\
\hline
\end{tabular}

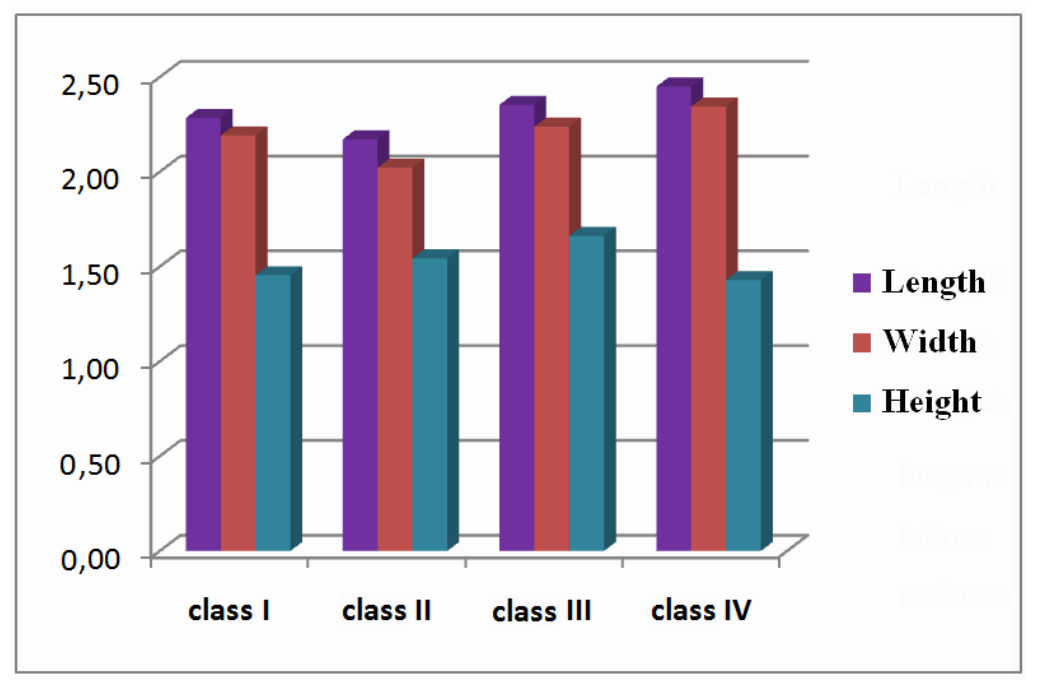

Graph 5. Evaluation of the Bonwill clasp: rests

The first evaluated were the Bonwill clasps.

Comparisons were made for occlusal rests / edentiation classes (graph 5) and significant width differences were obtained ( $p=0.042$ with significant limit $\alpha=0.05$ ).

Following the evaluation made with this program we obtained that the value of the width from the second class is significantly lower than that of the fourth class Kennedy $(p=0.047, \alpha=0.05)$

The same measurements were made for the occlusal rests of the Ackers clasp (Table 6), and the comparative evaluation by edentation classes is shown in Graph 6 . 
Table 6. Evaluation of ackers clasps rests

\begin{tabular}{|c|c|c|c|c|c|c|c|c|c|}
\hline \multirow{2}{*}{$\begin{array}{c}\text { Ackers } \\
\text { clasp } \\
\text { ocluzal rests }\end{array}$} & \multirow{2}{*}{ Class } & \multirow{2}{*}{ No. } & \multirow{2}{*}{ Average } & \multirow{2}{*}{$\begin{array}{l}\text { Standard } \\
\text { deviation }\end{array}$} & \multirow{2}{*}{$\begin{array}{l}\text { Standard } \\
\text { error of the } \\
\text { average }\end{array}$} & \multicolumn{2}{|c|}{$\begin{array}{l}95 \% \text { Confidence Interval } \\
\text { for the average }\end{array}$} & \multirow{2}{*}{ Min. } & \multirow{2}{*}{ Max. } \\
\hline & & & & & & $\begin{array}{c}\text { Inferior } \\
\text { limit }\end{array}$ & $\begin{array}{l}\text { Upper } \\
\text { limit }\end{array}$ & & \\
\hline \multirow{5}{*}{ Length } & I & 43 & 2.34 & 0.395 & 0.060 & 2.220 & 2.463 & 1.7 & 3.1 \\
\hline & II & 63 & 2.16 & 0.517 & 0.065 & 2.027 & 2.287 & 1.0 & 4.0 \\
\hline & III & 37 & 2.30 & 0.616 & 0.101 & 2.095 & 2.505 & 1.5 & 4.5 \\
\hline & IV & 15 & 1.91 & 0.449 & 0.116 & 1.665 & 2.162 & 1.4 & 2.5 \\
\hline & Total & 158 & 2.22 & 0.518 & 0.041 & 2.136 & 2.299 & 1.0 & 4.5 \\
\hline \multirow{5}{*}{ Width } & I & 43 & 2.30 & 0.420 & 0.064 & 2.171 & 2.429 & 1.5 & 3.3 \\
\hline & II & 63 & 2.30 & 0.445 & 0.056 & 2.193 & 2.417 & 1.2 & 3.0 \\
\hline & III & 37 & 2.18 & 0.342 & 0.056 & 2.070 & 2.298 & 1.5 & 3.0 \\
\hline & IV & 15 & 1.85 & 0.464 & 0.120 & 1.590 & 2.104 & 1.3 & 3.0 \\
\hline & Total & 158 & 2.23 & 0.436 & 0.035 & 2.163 & 2.300 & 1.2 & 3.3 \\
\hline \multirow{5}{*}{ Thickness } & I & 43 & 1.84 & 0.333 & 0.051 & 1.742 & 1.947 & 1.0 & 2.5 \\
\hline & II & 63 & 1.57 & 0.401 & 0.050 & 1.466 & 1.668 & 0.5 & 2.6 \\
\hline & III & 36 & 1.56 & 0.223 & 0.037 & 1.488 & 1.639 & 1.0 & 2.0 \\
\hline & IV & 15 & 1.67 & 0.354 & 0.091 & 1.471 & 1.863 & 1.3 & 2.5 \\
\hline & Total & 157 & 1.65 & 0.362 & 0.029 & 1.595 & 1.709 & 0.5 & 2.6 \\
\hline
\end{tabular}

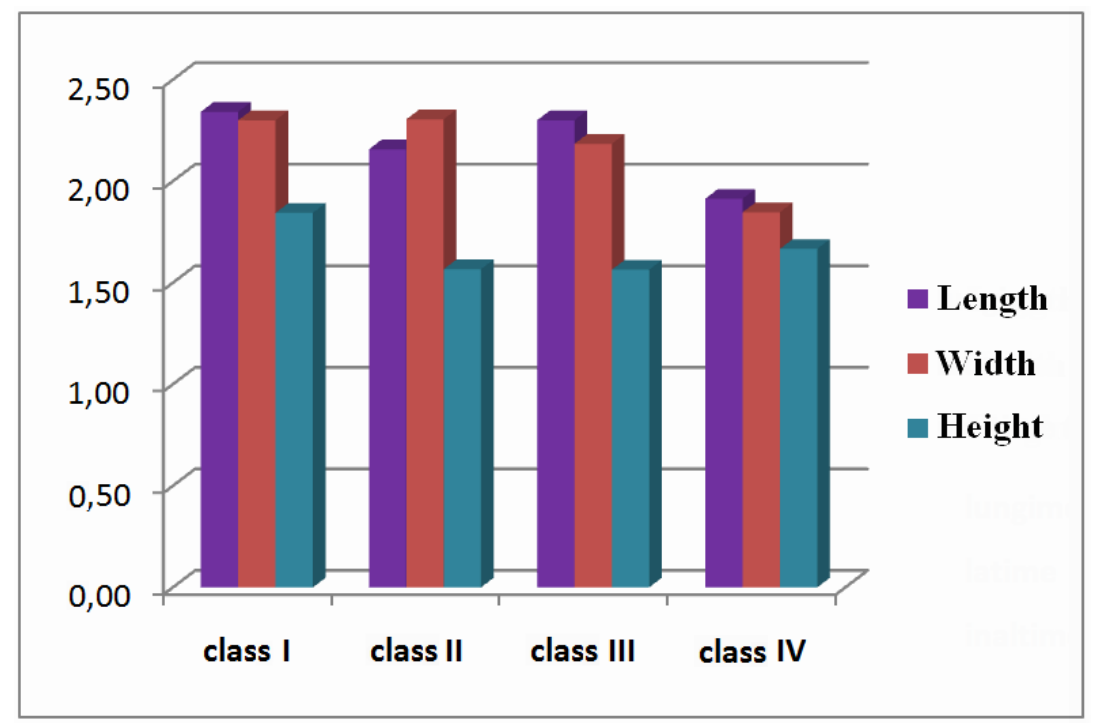

Graph 6. Evaluation of Ackers crochet occlusal rests

Significant differences in length $(\mathrm{p}=0.022, \alpha=0.05)$, width $(\mathrm{p}=0.001, \alpha=0.01)$ and height ( $\mathrm{p}$ $<0.001, \alpha=0.001$ ) were obtained when Akers clasps were assesed. By establishing the differences between the values of the occlusal rests of the Ackers clasps / edentation classes, significant differences were obtained in the cases:

- The length from class I is increased compared to the length of class IV ( $p=0.041, \alpha=0.05)$

- The widthfrom class I is increased compared to that of class IV ( $p=0.006, \alpha=0.01)$ 
- The widthfrom the II class is higher than that of the IV class $(\mathrm{p}=0.003, \alpha=0.01)$

- The height for class I is higher than the height for class II ( $p=0.001, \alpha=0.01)$

- The height for class I is higher than the height for class III $(p=0.006, \alpha=0.01)$

The results of the statistical studies regarding the area of junction between the body of the clasp and the retentive arm of the clasp are presented with the following characteristics for the Bonwill clasp (Table 7, Graph 7).

Table 7. Evaluation of the clasps body joint - retentive arm - bonwill clasp

\begin{tabular}{|c|c|c|c|c|c|c|c|c|c|}
\hline \multirow{2}{*}{$\begin{array}{l}\text { Bonwill clasp } \\
\text { junction between } \\
\text { the body of the } \\
\text { clasp and the } \\
\text { retentive arm }\end{array}$} & \multirow[b]{2}{*}{ Class } & \multirow[b]{2}{*}{ No. } & \multirow[b]{2}{*}{ Average } & \multirow[b]{2}{*}{$\begin{array}{l}\text { Standard } \\
\text { deviation }\end{array}$} & \multirow{2}{*}{$\begin{array}{l}\text { Standard } \\
\text { error of the } \\
\text { average } \\
95 \%\end{array}$} & \multicolumn{2}{|c|}{$\begin{array}{l}95 \% \text { confidence interval } \\
\text { for the average }\end{array}$} & \multirow[b]{2}{*}{ Min } & \multirow[b]{2}{*}{ Max } \\
\hline & & & & & & Inferior limit & $\begin{array}{l}\text { Upper } \\
\text { limit }\end{array}$ & & \\
\hline \multirow{5}{*}{ width } & I & 14 & 1.86 & 0.815 & 0.218 & 1.394 & 2.335 & 0.0 & 2.5 \\
\hline & II & 32 & 1.95 & 0.311 & 0.055 & 1.838 & 2.062 & 0.9 & 2.5 \\
\hline & III & 12 & 2.09 & 0.281 & 0.081 & 1.913 & 2.270 & 1.7 & 2.6 \\
\hline & IV & 19 & 1.87 & 0.216 & 0.049 & 1.770 & 1.978 & 1.5 & 2.2 \\
\hline & Total & 77 & 1.94 & 0.426 & 0.049 & 1.841 & 2.034 & 0.0 & 2.6 \\
\hline \multirow{5}{*}{ height } & I & 14 & 1.51 & 0.764 & 0.204 & 1.073 & 1.956 & 0.0 & 2.1 \\
\hline & II & 32 & 1.81 & 0.599 & 0.106 & 1.597 & 2.028 & 0.8 & 3.0 \\
\hline & III & 12 & 1.68 & 0.453 & 0.131 & 1.396 & 1.971 & 1.0 & 2.5 \\
\hline & IV & 19 & 1.64 & 0.445 & 0.102 & 1.422 & 1.851 & 0.8 & 2.0 \\
\hline & Total & 77 & 1.69 & 0.579 & 0.066 & 1.563 & 1.826 & 0.0 & 3.0 \\
\hline
\end{tabular}

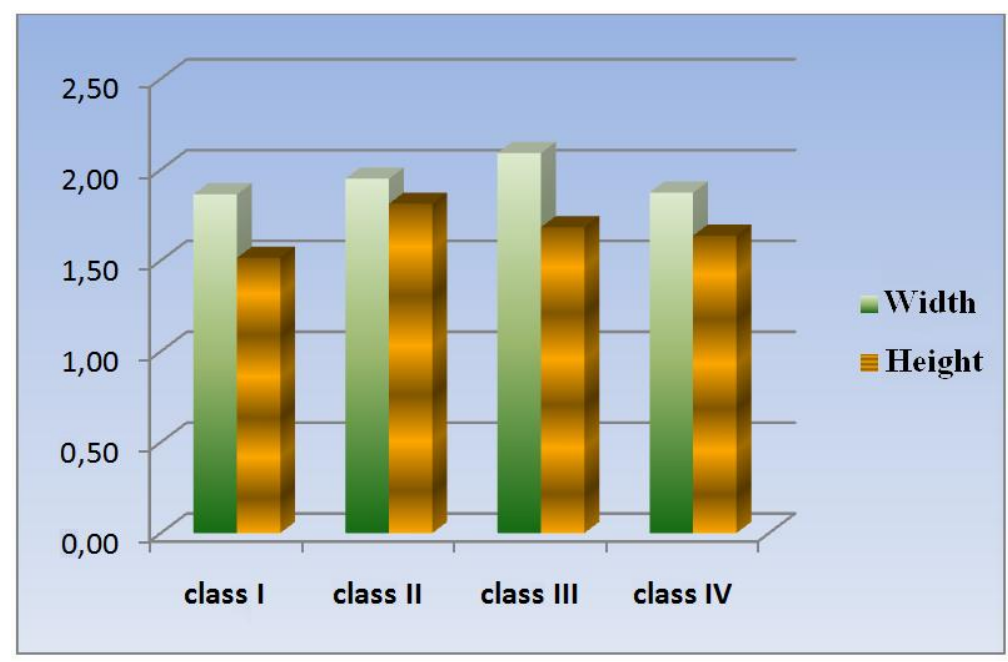

Graph 7. Bonwill crochet body / retention arm junction

For the junction of the Bonwill clasp body / retentive clasp arm, significant differences were obtained: for width $\mathrm{p}=0.494$, and in the case of height $\mathrm{p}=0.418$ was obtained.

The evaluation of the junction between the body of the clasp and the retentive arm of the Ackers clasp followed.The evaluations are shown in Table 8, and Chart 8. 
Table 8. Evaluation of the junction area between the ackers clasp body and the retentive arm

\begin{tabular}{|c|c|c|c|c|c|c|c|c|c|}
\hline \multirow{2}{*}{$\begin{array}{l}\text { Junction of } \\
\text { the Ackers } \\
\text { clasp body / } \\
\text { retentive } \\
\text { clasp arm }\end{array}$} & \multirow[b]{2}{*}{ Class } & \multirow[b]{2}{*}{ No. } & \multirow[b]{2}{*}{ Average } & \multirow[b]{2}{*}{$\begin{array}{l}\text { Standard } \\
\text { deviation }\end{array}$} & \multirow{2}{*}{$\begin{array}{c}\text { Standard } \\
\text { error of the } \\
\text { average } \\
95 \%\end{array}$} & \multicolumn{2}{|c|}{$\begin{array}{l}95 \% \text { confidence interval for } \\
\text { the average }\end{array}$} & \multirow[b]{2}{*}{ Min. } & \multirow[b]{2}{*}{ Max. } \\
\hline & & & & & & Inferior limit & $\begin{array}{l}\text { Upper } \\
\text { limit }\end{array}$ & & \\
\hline \multirow{5}{*}{ Width } & I & 42 & 1.81 & 0.330 & 0.051 & 1.707 & 1.912 & 0.9 & 2.5 \\
\hline & II & 64 & 1.74 & 0.387 & 0.048 & 1.647 & 1.841 & 1.0 & 2.5 \\
\hline & III & 37 & 1.94 & 0.209 & 0.034 & 1.871 & 2.010 & 1.5 & 2.3 \\
\hline & IV & 15 & 1.78 & 0.276 & 0.071 & 1.627 & 1.933 & 1.4 & 2.2 \\
\hline & Total & 158 & 1.81 & 0.334 & 0.027 & 1.758 & 1.863 & 0.9 & 2.5 \\
\hline \multirow{5}{*}{ Height } & I & 42 & 1.57 & 0.531 & 0.082 & 1.406 & 1.737 & 0.6 & 3.0 \\
\hline & II & 64 & 1.55 & 0.698 & 0.087 & 1.376 & 1.724 & 0.5 & 2.9 \\
\hline & III & 37 & 1.62 & 0.455 & 0.075 & 1.470 & 1.773 & 0.7 & 2.5 \\
\hline & IV & 15 & 1.55 & 0.370 & 0.096 & 1.348 & 1.758 & 0.9 & 2.0 \\
\hline & Total & 158 & 1.57 & 0.574 & 0.046 & 1.483 & 1.663 & 0.5 & 3.0 \\
\hline
\end{tabular}

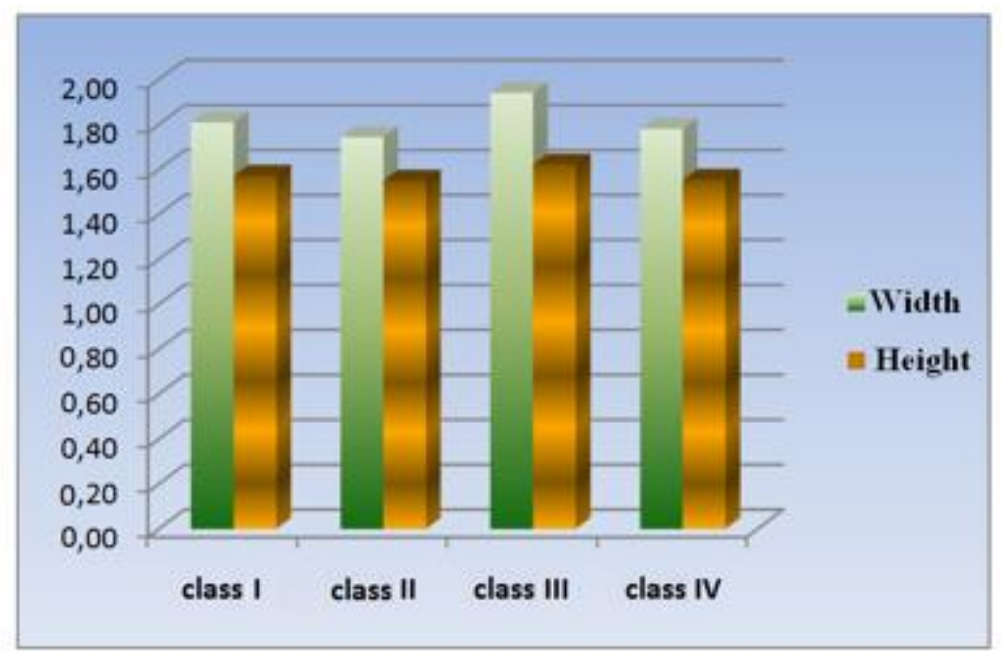

Graph 8. Ackers clasp body / retention arm junction

Significant differences were obtained at the junction of the Ackers clasp body / retentive clasp arm for the width of the retaining elements evaluated (ANOVA test, $p=0.38, \alpha=0.05$ ).

The width for class II is significantly smaller than the width for class III (post hoc Scheffe test, $\mathrm{p}=$ $0.041, \alpha=0.05)$.

When analyzing the size of the minor connector of the Bonwill clasp, results were presented in Table 9 and Graph 9.

Table 9. Evaluation of the profile of the secondary connector of the bonwill clasp

\begin{tabular}{|c|c|c|c|c|c|c|c|c|c|}
\hline \multirow{2}{*}{$\begin{array}{l}\text { Bonwill } \\
\text { clasp minor } \\
\text { connector }\end{array}$} & \multirow{2}{*}{ Class } & \multirow{2}{*}{ No. } & \multirow{2}{*}{ Average } & \multirow{2}{*}{$\begin{array}{l}\text { Standard } \\
\text { deviation }\end{array}$} & \multirow{2}{*}{$\begin{array}{l}\text { Standard } \\
\text { error of the } \\
\text { average }\end{array}$} & \multicolumn{2}{|c|}{$\begin{array}{l}95 \% \text { Confidence interval } \\
\text { for the average }\end{array}$} & \multirow{2}{*}{ Min. } & \multirow{2}{*}{ Max } \\
\hline & & & & & & $\begin{array}{l}\text { Inferior } \\
\text { limit }\end{array}$ & $\begin{array}{l}\text { Superior } \\
\text { limit }\end{array}$ & & \\
\hline \multirow{3}{*}{ length } & I & 14 & 5.27 & 0.517 & 0.138 & 4.973 & 5.570 & 4.1 & 6.1 \\
\hline & II & 34 & 5.41 & 0.736 & 0.126 & 5.155 & 5.669 & 4.0 & 7.1 \\
\hline & III & 13 & 4.95 & 0.653 & 0.181 & 4.559 & 5.348 & 3.9 & 6.1 \\
\hline
\end{tabular}




\begin{tabular}{|c|c|c|c|c|c|c|c|c|c|}
\hline & IV & 19 & 4.70 & 1.343 & 0.308 & 4.053 & 5.347 & 2.9 & 7.1 \\
\hline & Total & 80 & 5.14 & 0.913 & 0.102 & 4.941 & 5.347 & 2.9 & 7.1 \\
\hline \multirow{5}{*}{ width } & I & 14 & 2.09 & 0.182 & 0.049 & 1.988 & 2.198 & 1.9 & 2.5 \\
\hline & II & 34 & 1.99 & 0.311 & 0.053 & 1.885 & 2.103 & 1.3 & 2.9 \\
\hline & III & 13 & 2.25 & 0.285 & 0.079 & 2.082 & 2.426 & 1.9 & 2.9 \\
\hline & IV & 19 & 2.25 & 0.259 & 0.059 & 2.123 & 2.372 & 1.9 & 2.7 \\
\hline & Total & 80 & 2.11 & 0.295 & 0.033 & 2.048 & 2.179 & 1.3 & 2.9 \\
\hline \multirow{5}{*}{$\begin{array}{c}\text { Minimum } \\
\text { height }\end{array}$} & I & 14 & 1.51 & 0.433 & 0.116 & 1.264 & 1.764 & 0.9 & 2.0 \\
\hline & II & 34 & 1.24 & 0.272 & 0.047 & 1.143 & 1.333 & 0.7 & 1.7 \\
\hline & III & 13 & 1.32 & 0.303 & 0.084 & 1.140 & 1.506 & 0.8 & 1.8 \\
\hline & IV & 19 & 1.06 & 0.211 & 0.048 & 0.961 & 1.165 & 0.5 & 1.3 \\
\hline & Total & 80 & 1.26 & 0.328 & 0.037 & 1.186 & 1.332 & 0.5 & 2.0 \\
\hline \multirow{5}{*}{$\begin{array}{c}\text { Maximum } \\
\text { height }\end{array}$} & I & 14 & 2.06 & 0.357 & 0.095 & 1.851 & 2.263 & 1.5 & 2.6 \\
\hline & II & 34 & 2.15 & 0.323 & 0.055 & 2.040 & 2.266 & 1.6 & 3.0 \\
\hline & III & 13 & 2.08 & 0.460 & 0.128 & 1.799 & 2.355 & 1.4 & 2.7 \\
\hline & IV & 19 & 1.92 & 0.338 & 0.077 & 1.758 & 2.084 & 1.0 & 2.5 \\
\hline & Total & 80 & 2.07 & 0.362 & 0.040 & 1.988 & 2.149 & 1.0 & 3.0 \\
\hline
\end{tabular}

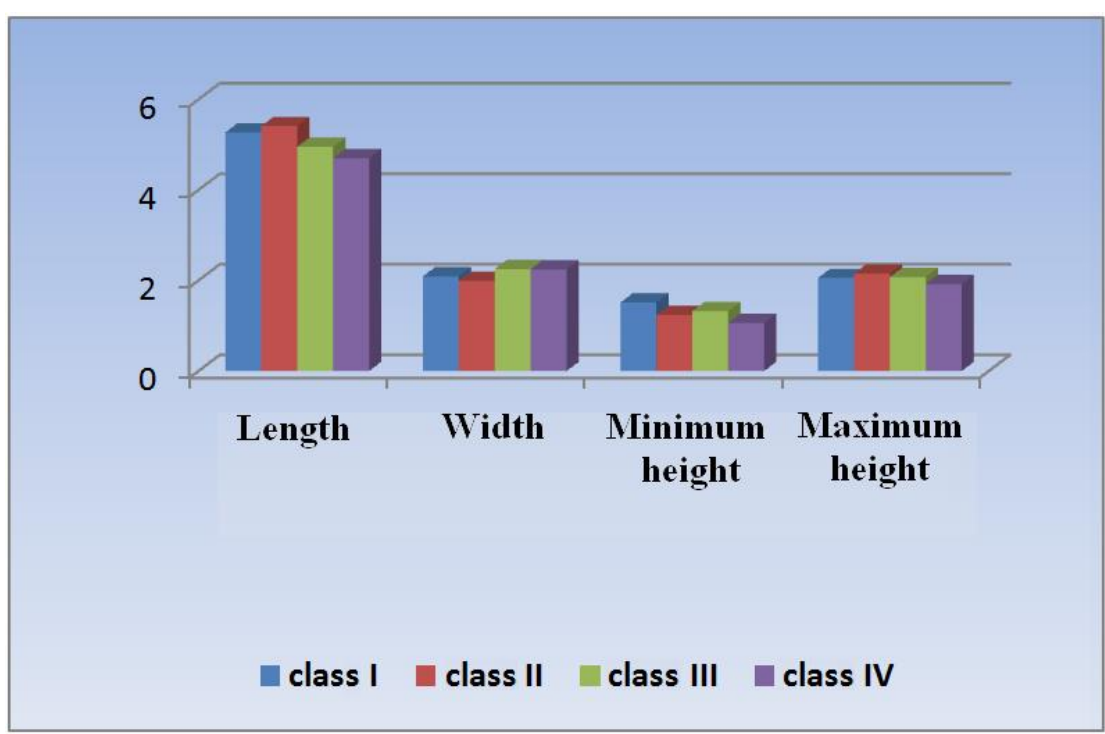

Graph 9. Bonwill minor connector evaluation

Comparing the classes they we obtained significant differences for the length $(\mathrm{p}=0.038$ with the significance limit $\alpha=0.05)$, width ( $p=0.004$ with the significance limit $\alpha=0.01)$ and minimum height ( $\mathrm{p}=0.001$ with the significance limit $\alpha=0.01$ ).For maximum height the differences between classes are insignificant ( $\mathrm{p}=0.17$ with the significance limit $\alpha=0.05)$.

Significant differences appeared in the situations:

- The length from class II is increased compared to the length of the IV class ( $p=0.045, \alpha=0.05)$

- The width from class III is greater than that of the II class $(p=0.047, \alpha=0.05)$

- The width from class IV is greater than that of class II $(p=0.022, \alpha=0.05)$

- The minimum height from class I is higher than that of class II $(p=0.044, \alpha=0.05)$

- The minimum height from class I is higher than in class IV $(p=0.001, \alpha=0.01)$

The data certifying the measurements made at the minor connector level of the Ackers clasp are detailed in table 10 and graph 10. 
Table 10. Evaluation of the profile of the minor connector of the ackers clasp

\begin{tabular}{|c|c|c|c|c|c|c|c|c|c|}
\hline \multirow{2}{*}{$\begin{array}{l}\text { Ackers clasp } \\
\text { minor } \\
\text { connector }\end{array}$} & \multirow{2}{*}{ Class } & \multirow{2}{*}{ No } & \multirow{2}{*}{ Average } & \multirow{2}{*}{$\begin{array}{c}\text { Std. } \\
\text { Deviation }\end{array}$} & \multirow{2}{*}{$\begin{array}{l}\text { Std. emor of } \\
\text { the average }\end{array}$} & \multicolumn{2}{|c|}{$\begin{array}{l}95 \% \text { Confidence interval } \\
\text { for the average }\end{array}$} & \multirow{2}{*}{ Min } & \multirow{2}{*}{ Max } \\
\hline & & & & & & $\begin{array}{l}\text { Inferior } \\
\text { limit }\end{array}$ & $\begin{array}{c}\text { Superior } \\
\text { limit }\end{array}$ & & \\
\hline \multirow{5}{*}{ Length } & I & 42 & 5.06 & 0.801 & 0.124 & 4.812 & 5.311 & 3.5 & 6.1 \\
\hline & II & 64 & 3.87 & 1.297 & 0.162 & 3.542 & 4.190 & 0.5 & 6.3 \\
\hline & III & 37 & 2.06 & 1.591 & 0.262 & 1.532 & 2.593 & 0.5 & 8.0 \\
\hline & IV & 15 & 4.71 & 2.376 & 0.613 & 3.391 & 6.022 & 0.5 & 7.0 \\
\hline & Total & 158 & 3.84 & 1.773 & 0.141 & 3.563 & 4.120 & 0.5 & 8.0 \\
\hline \multirow{5}{*}{ Width } & I & 42 & 2.04 & 0.253 & 0.039 & 1.964 & 2.122 & 1.2 & 2.5 \\
\hline & II & 64 & 1.89 & 0.404 & 0.051 & 1.788 & 1.990 & 1.1 & 2.7 \\
\hline & III & 37 & 2.51 & 0.844 & 0.139 & 2.232 & 2.795 & 1.4 & 4.6 \\
\hline & IV & 15 & 2.18 & 0.841 & 0.217 & 1.714 & 2.646 & 1.5 & 5.0 \\
\hline & Total & 158 & 2.10 & 0.607 & 0.048 & 2.008 & 2.199 & 1.1 & 5.0 \\
\hline \multirow{5}{*}{$\begin{array}{l}\text { Minimum } \\
\text { height }\end{array}$} & I & 42 & 1.15 & 0.252 & 0.039 & 1.074 & 1.231 & 0.7 & 2.0 \\
\hline & II & 64 & 1.19 & 0.317 & 0.040 & 1.113 & 1.271 & 0.5 & 2.0 \\
\hline & III & 37 & 1.26 & 0.319 & 0.052 & 1.156 & 1.369 & 0.8 & 2.0 \\
\hline & IV & 15 & 1.25 & 0.352 & 0.091 & 1.058 & 1.448 & 0.7 & 1.9 \\
\hline & Total & 158 & 1.20 & 0.305 & 0.024 & 1.156 & 1.252 & 0.5 & 2.0 \\
\hline \multirow{5}{*}{$\begin{array}{l}\text { Maximum } \\
\text { height }\end{array}$} & I & 42 & 1.38 & 0.220 & 0.034 & 1.312 & 1.450 & 1.1 & 2.1 \\
\hline & II & 64 & 1.54 & 0.313 & 0.039 & 1.459 & 1.616 & 0.9 & 2.2 \\
\hline & III & 37 & 1.47 & 0.329 & 0.054 & 1.361 & 1.580 & 0.9 & 2.1 \\
\hline & IV & 15 & 1.47 & 0.379 & 0.098 & 1.257 & 1.677 & 0.9 & 2.1 \\
\hline & Total & 158 & 1.47 & 0.306 & 0.024 & 1.425 & 1.521 & 0.9 & 2.2 \\
\hline
\end{tabular}

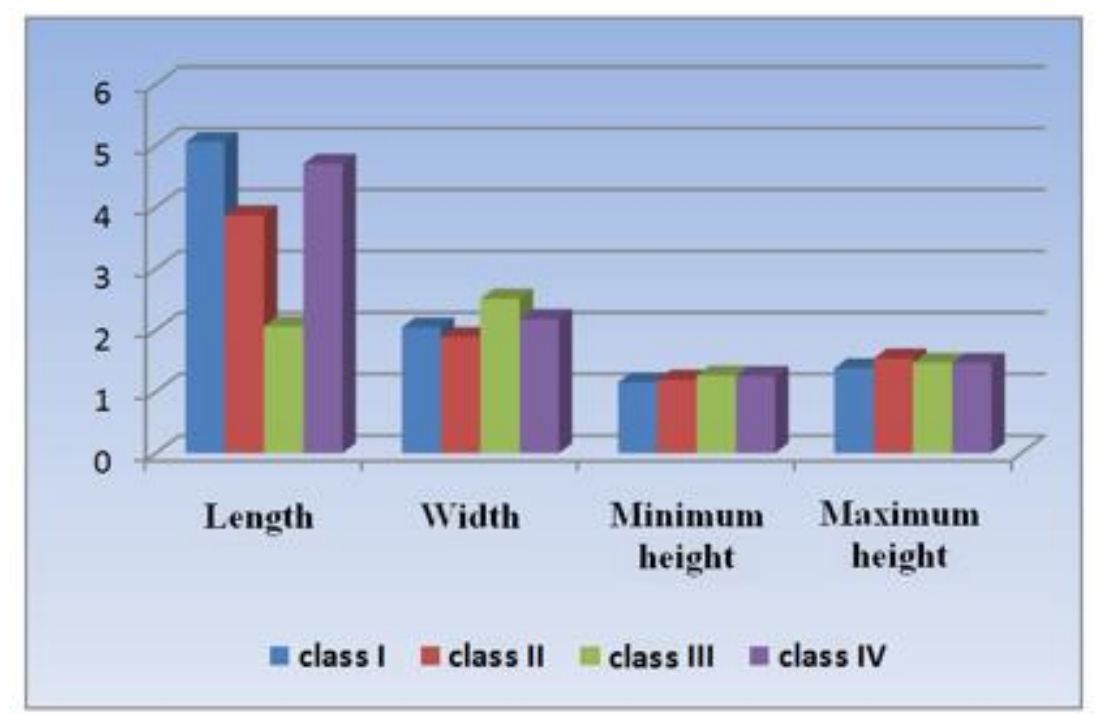

\section{Graph 10. Evaluation Ackers minor connector}

Comparisons between classes revealed significant differences for length $(p<0.001$ with significance limit $\alpha=0.001)$ and width $(\mathrm{p}<0.001$ with significance limit $\alpha=0.001)$. 
We obtained significant differences in the cases:

- The length from class I is increased compared to the length of class II ( $p=0.001, \alpha=0.01$ )

- The length from class I is greater than that of class III $(p<0.001, \alpha=0.001)$

- The length from class II is greater than that of class III ( $p<0.001, \alpha=0.001)$

- The length from class IV is greater than that of class III $(\mathrm{p}<0.001, \alpha=0.001)$

- The width from class III is higher than that of class I $(p=0.004, \alpha=0.01)$

- The width from the class III is higher than that of the second class $(p<0.001, \alpha=0.001)$

In the design of the removable partial dentures, an important role is played by the design of clasps. It is essential to achieve optimal pathways of the arms, in order for them to fulfill their basic function of retention, support and stabilization of the prosthesis [2- 4, 14- 16]. Based on mathematical calculations it has been shown that a shorter retentive arm has a holding force superior to a longer retentive arm, given the existence of the same retention depth, the same diameter and material. Also, at equal lengths and diameters, the holding force decreases proportionally to the modulus of elasticity. [17]. The diameter and shape influence, in addition to the length, the holding force, which is why the calibrated wax profiles gradually subside towards the top. By doubling the length of one arm under the conditions in which the other parameters are kept, an eight-fold lower force is considered sufficient to achieve elastic deformation. In contrast, if we double the width of the profile and keep the other parameters constant, a double force will be needed in order to achieve the elastic deformation. For a doubling of the thickness of the profile with the constant maintenance of the other parameters an eight times greater force will be needed to obtain the elastic deformation $[3,16,18]$.

The length, the width, the thickness, the sectional shape of the retentive arm, the degree of retention of the abutement tooth, but also the elastic properties of the material from which the clasps is made, influence the size of the retention of a clasp. $[15,16]$.

In the present study, the differences in length for the active arm of the Bonwill clasp are explained by the location of the clasp in the molar or premolar area, while the other criteria are related to the model.We believe that the width of the clasp should be the same, especially when working with calibrated wax. It turns out that the layout was done by pressing the wax, which increased the width.

The different length of the Ackers can be explained by positioning in the molar or premolar area. The results are focused on the different lengths of the opposing arms of the clasps, which are roughly modeled in the first 3 edentation classes, with a significant difference from those achieved in Kennedy's fourth-grade edentation, where these segments of the clasps are much shorter. There is no plausible explanation for this reality.The flexibility of the retentive arm must be large enough to not deform permanently over time the exercise of functions. By changing the length under the conditions of constant preservation of the other parameters, the flexibility of the clasp also changes, increasing with them. $[15,16,19]$.

The thickness per section also influences the flexibility, as it decreases, the flexibility increases. It has been found that the change in thickness has a greater influence than the width, and for the clasps cast with the hemispherical section it has been shown that the optimum width / thickness ratio is $2 / 1$. The dimensions from the base of the retentive arm must be double to those of the terminal portion, thus ensuring increased efficiency through the tapered shape [2-4]. The results of this study showed that the height (thickness) at the base or tip is a mistake, which starts from the wax model and which has not been corrected nor processed. The consequences are related to the lack of elasticity of the clasps and the possibility of their deterioration already from the processing. Interestingly, the thicknesses of the Ackers clasps are modeled differently depending on the type of edentation they solve. In this regard, it is inexplicable why the peak of the active arm of smaller thicknesses was achieved in the first-class edentations compared to the other edentations.

At present, there are pre-calibrated wax profiles and clasp systems (marketed by Austenal, Bios) on which the dimensions of the model are calculated exactly by a system specific to them. 
Comparing the values obtained by the measurements of the metal frameworks with those of the wax profiles, we observed large differences. In the literature we have found the following values considered optimal for the thickness of the component elements of the Ackers clasp: the clasp body, thickness: $1.5-2 \mathrm{~mm}$; the opposing arm with a thickness of 1.5-2 mm; minor connector: $2-3 \mathrm{~mm}$ thick; the retentive arm in the supraequatorial portion: $1.5-2 \mathrm{~mm} .[3,4,20]$. Piencos and Nazarova specify the optimum dimensions for an Ackers clasp as follows: clasp body, 1-1.5 mm thick; the active arm the rigid portion $1.5-2 \mathrm{~mm}$; the opposing arm of uniform thickness of $1.5-2 \mathrm{~mm}$; occlusal rest $2 \mathrm{~mm}$ thick; minor connector $2-3 \mathrm{~mm}$ thick $[21,22]$.

The present study shows dimensional changes of the retentive arms, and a significant number of clasps do not have retentive arms as a result of poor machining, where there was an improper connection of the area between the clasps body and the retentive arms, or a casting defect or processing.

It is known that by changing the width and the thickness in the sense of its increase, the resistance increases, but the changes in length have a smaller influence on it. The authors consider that the results of the study outline the basic principles by which the size and shape of the clasps can be optimized [23]. Luca NK and collaborators analyze mathematically the minimum dimensions of the occlusal rests necessary to ensure the support of the removable partial dentures and to transmit the occlusal forces in the long axis of the tooth. They conducted a study on two types of alloys: one of Co-Cr and another of titanium to which a force of $400 \mathrm{~N}$ is applied. The results of their study show that the minimum thickness for rests of the Co-Cr alloy must be at least $1.03 \mathrm{~mm}$ with a length of $2 \mathrm{~mm}$ and a width of 2 $\mathrm{mm}$, and for those from the thickness of the titanium must be at least $1.85 \mathrm{~mm}$ and a width of $2.7 \mathrm{~mm}$. At the same time, he points out that the decrease of one of the dimensions must be compensated by the increase of another [24]. Studies that had as main objective the preparations for occlusal and supracingular rests performed at the level of the teeth, found that most of the preparations did not meet the necessary criteria, due to insufficient preparations and insufficient interoclusal space. In these studies, it is understood that emphasis should be placed on the design aspects of prostheses in both educational programs and in the continuous medical training of the practitioners $[25,26]$.

In the present study, regarding the size of the rests, although their thickness approximates the values indicated in the literature, they do not register in the occlusal relief of the tooth. The occurence of interferences and premature contacts is undoubtedly affecting repercussions on the remaining tissues and on the components of the clasps.

From the graph realized, we observe that, the maximum height of the occlusal rests is in the thirdgrade edentation, where it should be the finest. However, the large length and width contribute to occlusal disharmony, because the occlusal rests rarely mimic the occlusal morphology of the tooth on which this type of clasp is applied. And in this case, it is confirmed that the oversizing of the occlusal rests regardless of the edentation class is still an unsolved problem well enough for future dental technicians. Even if their modeling is done in excess, it is necessary to process and model the external surface of the occlusal rests in accordance with the morphology of the tooth.

The thickness of the retentive arms and of the opposing arms in the results of this study, most have small thicknesses (compared to those mentioned in the literature) in the area of passage from the occlusal face (joining with the occlusal restss and body of the clasps) to the vestibular and oral faces of the tooth. We consider that improved preparations at this level are necessary because they are insufficient at the level of occlusal embrasures.

From the point of view of the minor connectors, it is observed the modification of the conformation of the interdental space. Often the position of the minor connectors is not straight and oblique to the major connector, because of the desire to shorten the maxillary mucosal plates in particular. The largest length of the minor connectors appears on the metal components that solve Kennedy's firstclass edentation. Measurements focused mainly on maxillary assessments, which would explain the increased two-dimensional size of these connectors. 


\section{Conclusions}

The length of the retentive arms varies depending on the classes of edentation, the clinical situation, but also on the size and type of the tooth (premolars, molars) on which the clasp is applied.

Regarding the width at the base of the retentive arm, dimensions smaller than those reported in the specialized literature were found in the case of clasps located in aesthetically important areas.

The width at the top of the retentive arm varies depending on the edentation class and the position of the clasp on the arch.

Regarding the opposing arm, the observed differences cannot be correlated with the objective criteria of their achievement, because the attention is directed towards the realization of the retentive arm.

\section{References}

1.AlAGEEL, O., ALSHEGHRI, A.A., ALGEZANI, S., CARON, E., TAMIMI, F., Determining the retention of removable partial dentures. J Prosthet Dent.;122(1): 2019, p 55-62. e3.

2. ABIODUN OLABISI ARIGBEDE, OLUWOLE O DOSUMU, TEMITOPE AYODEJI ESAN, PATRICIA A AKEREDOLUM, Acceptability of maxillary major connectors in removable partial dentures, Afr Health Sci.;6(2), 2006, p 113-117.

3.NICK POLYCHRONAKIS, MICHAEL SOTIRIOU, ALCIBIADES ZISSIS, A Survey of Removable Partial Denture (RPD) Retentive Elements in Relation to the Type of Edentulism and Abutment Teeth Found in Commercial Laboratories, Athens, Greece, Acta Stomatol Croat.,48(3),2014, p 199-207.

4.SHERIF ALY SADEK, WESSAM MOHAMED DEHIS, HALA HASSAN, Comparative Study Clarifying the Most Suitable Material to Be Used as Partial Denture Clasps, Open Access Maced J Med Sci. 20(6): 2018 p 1111-1119.

5.CAMPBELL, S.D., COOPER L., CRADDOCK H., HYDE T.P., NATTRESS B., PAVITT S.H., SEYMOUR D.W.Removable partial dentures - The clinical need for innovation, The Journal of Prosthetic Dentistry, 118(3), 2017, p.273-280

6. MARIE, A., KEELING, A., HYDE, T.P., NATTRESS, B.R, PAVITT, S., MURPHY R.J., SHARY, T.J., DILLON, S., OSNES C, - Deformation and retentive force following in vitro cyclic fatigue of cobalt-chrome and aryl ketone polymer (AKP) clasps, Dental materials 2019, 35(6), p 113-121

7.QUINEY D, AYRE WN, MILWARD P - The effectiveness of adhesives on the retention of mandibular free end saddle partial dentures: An in vitro study, .62: 2017, p. 64-71,

8.A TOKUE, T. HAYAKAWA, CHIKAHIRO OHKUBO - Fatigue resistance and retentive force of cast clasps treated by shot peening, Journal of Prosthodontic Research 57, 2013, p 186-194.

9.BORŢUN, C., MITELEA, I., MILOŞ, L., BÎRDEANU, V., SANDU, L. - Analysis of laser welded joints on $\mathrm{C}$ alloy used in removable partial dentures technology, European Cells and Materials, 10, 2005 , p. 31

10.MOHAMMAD TAREK M. ANAN 1, MOHANNAD H. AL-SAADI - Fit accuracy of metal partial removable dental prosthesis frameworks fabricated by traditional or light curing modeling material technique: An in vitro study The Saudi Dental Journal, 27, 2015, p 149-154.

11.DONOVAN, T.E., MARZOLA, R., MURPHY, K.R., CAGNA D.R., EICHMILLER F., MCKEE, J.R., METZ, J.E., ALBOUY, J.P., TROELTZSCH, M., Annual review of selected scientific literature: A report of the Committee on Scientific Investigation of the American Academy of Restorative Dentistry, J. Prosthet. Dent.,120, 2018, p. 816-78.

12.RIYADH AKEEL -Usage of removable partial dentures in Saudi male patients after 1-year telephone interview, The Saudi Dental Journal, 22, 2010, p 125-128.

13.FUEKI, K., OHKUBO, C., YATABE, M., ARAKAWA, I., ARITA, M., INO, S., KANAMORI, T., KAWAI, Y., KAWARA, M., KOMIYAMA, O., SUZUKI, T., NAGATA, K., HOSOKI M., MASUMI, S., YAMAUCHI, M., AITA, H., ONO, T., KONDO, H., TAMAKI, K., MATSUKA, Y., TSUKASAKI, H., FUJISAWA, M., BABA, K., KOYANO, K., YATANI, H., Clinical application of 
removable partial dentures using thermoplastic resin. Part II: Material properties and clinical features of non-metal clasp dentures, Journal of prosthodontic research 58, 2014, p $71-84$.

14. MERCUT, V., SCRIECIU, M., SUCIU, M., POPESCU, M, SFREDEL, V., IORGULESCU, D., MARASESCU, P., MERCUT,, R. - Modifications of the morphology of the dental - maxillary apparatus consecutive to bruxism, Medicine in Evolution 16(4), 2010, p 39-46.

15. BORŢUN, C., SANDU, L., LERETTER, M., SAMOILA, C. - Modalităţi practice de optimizare a retenţiei croşetelor turnate, Revista Naţională de Stomatologie, Chirurgie Maxilo - Facială şi Chirurgie Orală,1(4), 2003, p. $50-56$.

16. GAMAN, S., BORTUN, C.M, MERCUT, V., ARDELEAN, L., RUSU, L. C., - Tehnici de optimizare a retenţiei croşetelor turnate, Rev. Chim., 63(8), 2012. 797 - 803.

17. LUCA, N.K., WU, VH., LIANG, B.M., CHEN, Y.M., YIP, K.H., SMALES, R.J., - Mathematical analysis of occlusal rest design for cast removable partial dentures. Eur. Prosthodont. Restor. Dent., 15(1), 2007, p 29-32.

18.NAZAROVA, E., TAYLOR, T.D., -The RPH clasp assembly: a simple alternative to traditional designs.J. Prosthodont., 21(4), 2012, p 331-3.

19.SATO, Y., SHIMODAIRA, O., KITAGAWA, N., - Systematic clinical evaluation and correction procedures for support of removable partial dentures. J Prosthodont. Apr;17(3): 2008, p 228-32.

20.PIENKOS, T.E., MORRIS, W.J., GRONET, P.M., CAMERON, S.M., LOONEY, S.W., - The strength of multiple major connector designs under simulated functional loading. J. Prosthent., 5, 2007, p 299-304.

21.NAZAROVA, E., TAYLOR, T.D., -The RPH clasp assembly: a simple alternative to traditional designs.J. Prosthodont. 21(4), 2012, p 331-3.

22.BEHR, M., ZEMAN, F., PASSAUER. T., KOLLER, M., HAHNEL, S., BUERGERS, R., LANG, R.,HANDEL, G., KOLBECK, C., -Clinical performance of cast clasp-retained removable partial dentures: a retrospective study. Int J Prosthodont., 25(2): 2012, p 138-44.

23.BORŢUN, C., CERNESCU, A., FAUR, N., SANDU, L., TOPALĂ, F., - Reverse Engineering and Finite Elements Analysis in Removable Partial Denture. Program and Abstracts Swiss Society for Biomaterials, 13th General Meeting, 9 may 2007, Neuchatel, Elveţia European Cells and Materials; 3(13): 2007, p 27.

24.LUCA, N.K., WU V.H., LIANG, B.M., CHEN, Y.M., YIP, K.H., SMALES, R.J., Mathematical analysis of occlusal rest design for cast removable partial dentures. Eur. Prosthodont. Restor. Dent., 15(1), 2007, p 29-32.

25.ALHELAL, A., KATTADIYIL, M.T., JEKKI, B., - Tooth: An Alternative Option Ring Rest Seat Design for Severely Tilted Molar Abutment. J. Prosthodont., 26(4): 2017, p.327-330.

26.RICE, J.A., LYNCH, C.D., MCANDREW, R., MILWARD, P.J., - Tooth preparation for rest seats for cobalt-chromium removable partial dentures completed by general dental practitioners $\mathrm{J}$ Oral Rehabil. ;38(1): 2011, p.72-8.

Manuscript received: 5. 05. 2020 